\title{
A one-dimensional barium(II) coordination polymer with a coordinated nitro group of 2-nitrobenzoate*
}

\author{
BIKSHANDARKOIL R SRINIVASAN ${ }^{1, \#}$, SANTOSH Y SHETGAONKAR ${ }^{1}$ and \\ PALLEPOGU RAGHAVAIAH ${ }^{1,2}$ \\ ${ }^{1}$ Department of Chemistry, Goa University, Goa 403206 \\ ${ }^{2}$ School of Chemistry, University of Hyderabad, Hyderabad 500046 \\ e-mail: srini@unigoa.ac.in
}

MS received 15 November 2007; accepted 24 January 2008

\begin{abstract}
The aqueous reaction of barium carbonate with 2-nitrobenzoic acid (2-nbaH) results in the formation of a one-dimensional coordination polymer, catena-poly[[hexa(aqua)dibarium(II)]bis $\left[\left(\mu_{2}-2-\right.\right.$ nitrobenzoate- $\left.\mathrm{O}, \mathrm{O}, \mathrm{O}-\mathrm{NO}_{2}\right)\left(\mu_{2}-2\right.$-nitrobenzoate- $\left.\left.\left.\mathrm{O}, \mathrm{O}, \mathrm{O}^{\prime}\right)\right]\right] \mathbf{1}$. On heating at $100^{\circ} \mathrm{C}$ compound 1 is dehydrated to anhydrous barium bis(2-nitrobenzoate) 2 . The anhydrous compound can be re-hydrated to 1 on exposure to water vapour. Compounds 1 and 2 were characterized by elemental analysis, IR and UV-Vis spectra, DSC thermograms, weight loss studies and the structure of 1 was determined. 1 and 2 can be thermally decomposed to $\mathrm{BaCO}_{3}$ by heating at $800^{\circ} \mathrm{C}$. The polymer $\left[\left[\mathrm{Ba}\left(\mathrm{H}_{2} \mathrm{O}\right)_{3}\right]_{2}\left(\mu_{2}-2-\mathrm{nba}-\mathrm{O}, \mathrm{O}, \mathrm{O}-\mathrm{NO}_{2}\right)_{2}\right.$ $\left.\left(\mu_{2}-2 \text {-nba- } \mathrm{O}, \mathrm{O}, \mathrm{O}^{\prime}\right)_{2}\right]_{n} \mathbf{1}$ crystallizes in the centrosymmetric triclinic space group $\mathrm{P} \overline{1}$ and all atoms are located in general positions. The polymeric structure is based on a dimeric unit and consists of three water molecules coordinated to a central $\mathrm{Ba}(\mathrm{II})$ and two unique 2-nitrobenzoate (2-nba) anions, one of which $\left(\mu_{2}-2\right.$ nba- $\mathrm{O}, \mathrm{O}, \mathrm{O}-\mathrm{NO}_{2}$ ) functions as a tridentate ligand and is linked to a $\mathrm{Ba}(\mathrm{II})$ through the oxygen atom of the $-\mathrm{NO}_{2}$ group and forms a monoatomic $\mu_{2}$-carboxylate bridge between two symmetry related $\mathrm{Ba}$ (II) ions with a $\mathrm{Ba} \cdots \mathrm{Ba}$ distance of $4 \cdot 5726(14) \AA$. The second unique 2 -nba anion $\left(\mu_{2}-2\right.$-nba-O,O, $\left.\mathrm{O}^{\prime}\right)$ also functions as a tridentate ligand with the carboxylate oxygen atoms linked to a $\mathrm{Ba}$ (II) ion in a bidentate fashion and one of the carboxylate oxygen atoms forming a monoatomic bridge between two symmetry related $\mathrm{Ba}$ (II) ions

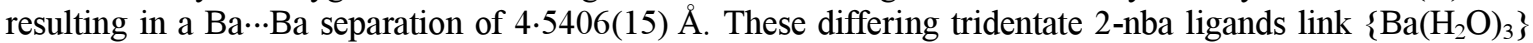
units into a one-dimensional polymeric chain extending along $b$ axis. In the infinite chain each nine coordinated $\mathrm{Ba}(\mathrm{II})$ is bonded to three water molecules and further linked to six oxygen atoms of four different 2-nitrobenzoate anions with alternating pairs of $\mathrm{Ba}$ (II) ions in the chain bridged by a pair of $\left(\mu_{2}-2-n b a-\right.$ $\left.\mathrm{O}, \mathrm{O}, \mathrm{O}-\mathrm{NO}_{2}\right)$ and $\left(\mu_{2}-2\right.$-nba-O,O, $\left.\mathrm{O}^{\prime}\right)$ ligands resulting in alternating $\mathrm{Ba} \cdots \mathrm{Ba}$ distances of $4 \cdot 5406(15)$ and $4 \cdot 5726(14) \AA$ across the chain.
\end{abstract}

Keywords. Coordination polymer; catena-poly[[hexa(aqua)dibarium(II)]bis[( $\mu_{2}-2$-nitrobenzoato-O,O,O$\left.\mathrm{NO}_{2}\right)\left(\mu_{2}\right.$-2-nitrobenzoato- $\left.\left.\mathrm{O}, \mathrm{O}, \mathrm{O}^{\prime}\right)\right]$ ]; nitro ligation; tridentate; monoatomic bridge; nine coordination.

\section{Introduction}

Although an extensive chemistry of metal carboxylates has been developed ${ }^{1,2}$ this field continues to attract the attention of several researchers in view of the importance of metal carboxylates in bioinorganic chemistry, catalysis, porous materials, etc. The use of carboxylic acids as ambidentate and templating ligands for the synthesis of novel coordination polymers, with metals providing interesting connectivity, is an area of topical research. ${ }^{3,4} \mathrm{~A}$ few years ago we initiated a research programme on metal carboxy-

*Dedicated to Prof. S. K. Paknikar on the occasion of his 73 rd birthday. "For correspondence lates $^{5}$ and as part of this program we are investigating the synthesis, structural aspects and thermal properties of metal 4-nitrobenzoate (4-nba) complexes. ${ }^{6-7}$ The structurally characterized compounds $\left[\mathrm{Mg}\left(\mathrm{H}_{2} \mathrm{O}\right)_{6}\right]$ $(4-n b a)_{2} \cdot 2 \mathrm{H}_{2} \mathrm{O}, \quad\left[\mathrm{Ca}\left(\mathrm{H}_{2} \mathrm{O}\right)_{4}(4-n b a-O)\left(4-n b a-O, \mathrm{O}^{\prime}\right)\right]$, $\left[\mathrm{Sr}\left(\mathrm{H}_{2} \mathrm{O}\right)_{7}\left(4-n b a-\mathrm{O}, \mathrm{O}^{\prime}\right)\right](4-\mathrm{nba}) \cdot 2 \mathrm{H}_{2} \mathrm{O}, \quad\left[\left[\mathrm{Ba}\left(\mathrm{H}_{2} \mathrm{O}\right)_{5}\right.\right.$ $\left.\left.\left(4-n b a-O, O^{\prime}\right)\right]\left(\mu_{2}-4-n b a-O, O^{\prime}\right)\right]_{n}, \quad\left[\mathrm{Mg}\left(\mathrm{H}_{2} \mathrm{O}\right)_{2}(\mathrm{Im})_{2}(4-\right.$ nba-O $\left.)_{2}\right] \quad(\mathrm{Im}=$ imidazole $), \quad\left[\mathrm{Mg}\left(\mathrm{H}_{2} \mathrm{O}\right)(\mathrm{N}-\mathrm{MeIm})_{2}\right.$ $\left.(4-n b a-O)\left(\mu_{2}-4-n b a-O, O^{\prime}\right)\right]_{2} \quad(N-M e I m=N-m e t h y l-$ imidazole), and $\left[\mathrm{Ca}\left(\mathrm{H}_{2} \mathrm{O}\right)_{3}(\mathrm{Im})(4-\mathrm{nba}-\mathrm{O})_{2}\right] \cdot \mathrm{Im}$, serve to demonstrate the rich structural chemistry of the alkali-earth 4-nitrobenzoates and the versatile ligational behaviour of 4-nba. ${ }^{8-12}$ An important structural feature of all these compounds is the $\mathrm{H}$ bonding characteristics of the $-\mathrm{NO}_{2}$ functionality of 
the 4-nba anion with the nitro oxygen atom functioning as a H-bond acceptor and the coordinated or lattice water molecules providing the $\mathrm{H}$-donors. In one-dimensional polymer ${ }^{12}\left[\left[\mathrm{Ba}\left(\mathrm{H}_{2} \mathrm{O}\right)_{5}\left(4-\mathrm{nba}-\mathrm{O}, \mathrm{O}^{\prime}\right)\right]\right.$ $\left.\left(\mu_{2}-4-n b a-O, \mathrm{O}^{\prime}\right)\right]_{n}$ the $-\mathrm{NO}_{2}$ group is involved in several $\mathrm{O}-\mathrm{H} \cdots \mathrm{O}$ and $\mathrm{C}-\mathrm{H} \cdots \mathrm{O}$ interactions with the $-\mathrm{NO}_{2}$ groups in one polymeric chain hydrogen bonded with the coordinated waters and aromatic hydrogen atoms on an adjacent chain. In order to gain more insight on the structure directing influence of the $-\mathrm{NO}_{2}$ group, we have now initiated a systematic study of the structural chemistry of compounds derived from the isomeric 2- and 3-nitrobenzoic acids. The vibrational spectral characteristics of 2- and 3 -nitrobenzoates of alkali metals like $\mathrm{Li}, \mathrm{Na}, \mathrm{K}, \mathrm{Rb}$ and $\mathrm{Cs}$ have been recently reported. ${ }^{13,14}$ It is interesting to note that the positioning of the $-\mathrm{NO}_{2}$ functionality ortho to the $-\mathrm{COOH}$ group in 2-nitrobenzoic acid (2-nbaH) results in the formation of a polymeric $\mathrm{Ba}(\mathrm{II})$ compound $\mathbf{1}$, the structure of which contains a nitro group coordinated to $\mathrm{Ba}$ (II). The results of these investigations are described in this paper.

\section{Experimental}

\subsection{Materials and methods}

All the chemicals used in this study were of reagent grade and were used as received. 2-nitrobenzoic acid (2-nbaH) was prepared by the oxidation of 2nitrobenzaldehyde with $30 \% \mathrm{H}_{2} \mathrm{O}_{2}$ in aqueous methanol. The starting materials and reaction products are air stable and hence were prepared under normal laboratory conditions. The details of the instrumentation used for IR and UV-Vis spectra, DSC and weight loss studies are the same as described in our earlier report. ${ }^{12}$ Single crystal X-ray diffraction study was performed at the National single crystal $\mathrm{X}$-ray facility at School of Chemistry, University of Hyderabad.

2.2 Preparation of $\left[\left[\mathrm{Ba}\left(\mathrm{H}_{2} \mathrm{O}\right)_{3}\right]_{2}\left(\mu_{2}-2-n b a-O, O, O-\right.\right.$ $\left.\left.\mathrm{NO}_{2}\right)_{2}\left(\mu_{2}-2-n b a-O, O, \mathrm{O}_{2}\right)_{2}\right]_{n} \mathbf{I}$

A mixture of barium carbonate $(1.98 \mathrm{~g}, 10 \mathrm{mmol})$ and 2-nitrobenzoic acid (2-nbaH) (3.34 g, $20 \mathrm{mmol})$ was taken in water $(50 \mathrm{ml})$ and heated on a steam bath. The insoluble $\mathrm{BaCO}_{3}$ slowly started dissolving accompanied with brisk effervescence. The heating of the reaction mixture was stopped when there was no more evolution of $\mathrm{CO}_{2}$. At this stage, the reaction mixture was almost clear. The hot solution was filtered and left undisturbed for 7-8 days. The colourless crystalline blocks that separated were filtered, washed thoroughly with ether and dried. Yield: $4.430 \mathrm{~g}(85 \%)$. The crystals obtained in this method were suitable for X-ray studies. 1 can also be prepared starting from $\mathrm{BaCl}_{2}$ as the $\mathrm{Ba}$ source. The sodium salt of 2-nba was first generated in situ by reacting 2-nbaH $(1.67 \mathrm{~g}, 10 \mathrm{mmol})$ with $\mathrm{NaHCO}_{3}$ $(0.84 \mathrm{~g}, 10 \mathrm{mmol})$ in water. Into this, an aqueous solution of $\mathrm{BaCl}_{2} \cdot 4 \mathrm{H}_{2} \mathrm{O} \quad(1.221 \mathrm{~g}, 5 \mathrm{mmol})$ was added and the reaction mixture was filtered and left aside for crystallization. The crystals that separated after a few days were isolated in $81 \%$ yield. The IR spectrum and the DSC thermogram of the product obtained in this method were identical to that of the product obtained using $\mathrm{BaCO}_{3}$ as the $\mathrm{Ba}$ source.

Anal. found (calcd.) for $\mathrm{C}_{14} \mathrm{H}_{14} \mathrm{BaN}_{2} \mathrm{O}_{11}$ (523.61): Ba, 25.50 (26.33); 2-nbaH, 62.99 (63.83); C, 31.53 (32.46); H, 2.49 (2.7); N 4.91 (5.41).

IR (in $\mathrm{cm}^{-1}$ ): 3730-2922 (br), $2833(w), 2525(w)$, $1815(w), 1594(s), 1566(s), 1552(s), 1537(m)$, $1523(s), 1512(s), 1504(m), 1478(s), 1440(s)$, $1404(s), 1393(s), 1347(s), 1308(s), 1265(w)$, $1248(w), 1144(w), 1076(w), 1037(w), 1013(w)$, $863(\mathrm{~m}), 841(\mathrm{~s}), 786(s), 735(s), 702(s), 679(w)$, $630(\mathrm{~m}), 513(\mathrm{~s}), 428(\mathrm{~s})$.

UV-vis: $274 \mathrm{~nm}\left(\varepsilon=14,0001 \mathrm{~mol}^{-1} \mathrm{~cm}^{-1}\right)$.

DSC (in ${ }^{\circ} \mathrm{C}$ ): 88 (Endo), 230 (Endo), 277 (Endo), 338 (Exo), 444 (Exo).

\subsection{Preparation of barium bis(2-nitrobenzoate) 2}

A powdered sample of $1(0.350 \mathrm{~g})$ was heated on a steam bath for $15 \mathrm{~min}$. This resulted in the formation of the anhydrous compound 2 . The observed mass loss of $10.5 \%$ is in good agreement with the expected value $(10 \cdot 32 \%)$ for the loss of three moles of water.

IR (in $\mathrm{cm}^{-1}$ ): $3086(w), 3068(w), 3032(w), 2852$ $(w), 1593(s), 1568(s), 1554(s), 1530(s), 1520(s)$, $1477(\mathrm{~m}), 1437(\mathrm{~s}), 1415(\mathrm{~s}), 1404(\mathrm{~s}), 1341(\mathrm{~s})$, $1310(s), 1261(s), 1142(s), 1074(s), 1039(w), 964$ $(w), 862(s), 837(s), 775(s), 780(s), 754(s), 702$ $(s), 648(s), 534(w), 630(m), 432(s)$.

DSC (in ${ }^{\circ} \mathrm{C}$ ): 231 (Endo), 272 (Endo), 336 (Exo), $450($ Exo $)$. 
Table 1. Technical details of data acquisition and selected refinement results for $\left[\left[\mathrm{Ba}\left(\mathrm{H}_{2} \mathrm{O}\right)_{3}\right]_{2}\left(\mu_{2}-2 \text {-nba-O,O,O-NO }\right)_{2}\left(\mu_{2}-2 \text {-nba-O, } \mathrm{O}, \mathrm{O}^{\prime}\right)_{2}\right]_{n} \mathbf{1}$.

\begin{tabular}{ll}
\hline Empirical formula & $\mathrm{C}_{14} \mathrm{H}_{14} \mathrm{BaN}_{2} \mathrm{O}_{11}$ \\
Formula weight & $523 \cdot 61 \mathrm{~g} \mathrm{~mol}^{-1}$ \\
Temperature & $293(2) \mathrm{K}$ \\
Wavelength & $0 \cdot 71073 \AA$ \\
Crystal system & Triclinic \\
Space group & $\mathrm{P} \overline{1}$ \\
Unit cell dimensions & $a=8 \cdot 360(3) \AA, \alpha=79 \cdot 78(6)^{\circ}$ \\
& $b=8 \cdot 475(3) \AA, \beta=85 \cdot 52(5)^{\circ}$ \\
& $c=14 \cdot 077(6) \AA, \gamma=70 \cdot 49(5)^{\circ}$ \\
Volume & $925 \cdot 0(6) \AA^{3}$ \\
$Z$ & 2 \\
Density (calculated) & $1 \cdot 880 \mathrm{mg}^{3} \mathrm{~m}^{3}$ \\
Absorption coefficient & $2 \cdot 209 \mathrm{~mm}^{-1}$ \\
$F(000)$ & 512 \\
Crystal size & $0 \cdot 42 \times 0 \cdot 34 \times 0 \cdot 20 \mathrm{~mm}^{3}$ \\
Theta range for data collection & $2 \cdot 58$ to $25 \cdot 85^{\circ}$ \\
Index ranges & $-10<=h<=10,-10<=k<=10,-17<=1<=17$ \\
Reflections collected & 8554 \\
Independent reflections & $3526[R($ int $)=0 \cdot 0187]$ \\
Completeness to theta $=26 \cdot 06^{\circ}$ & $98 \cdot 6 \%$ \\
Refinement method & Full-matrix least-squares on $F^{2}$ \\
Data/restraints/parameters & $3526 / 9 / 271$ \\
Goodness-of-fit on $F^{2}$ & $1 \cdot 113$ \\
Final $R$ indices $[I>2 \sigma(\mathrm{I})]$ & $R 1=0 \cdot 0227, w R 2=0.0589$ \\
$R$ indices (all data) & $R 1=0 \cdot 0230, w R 2=0 \cdot 0592$ \\
Extinction coefficient & $0 \cdot 0040(2)$ \\
Largest diff. peak and hole & $0 \cdot 707$ and $-0 \cdot 885$ e $\AA^{-3}$ \\
\hline
\end{tabular}

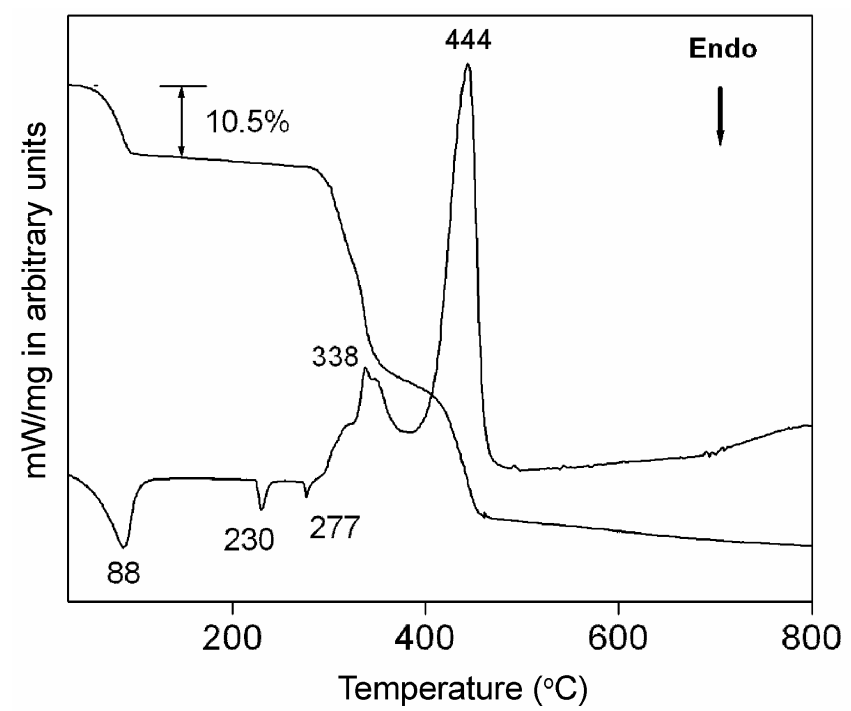

Figure 1. TG-DSC thermogram of $\left[\left[\mathrm{Ba}\left(\mathrm{H}_{2} \mathrm{O}\right)_{3}\right]_{2}\left(\mu_{2}-2-\right.\right.$ nba-O, $\left.\left., 0,-\mathrm{NO}_{2}\right)_{2}\left(\mu_{2}-2-\text { nba-O, }, \mathrm{O}^{\prime}\right)_{2}\right]_{n}$ 1. (Heating rate $10 \mathrm{~K} / \mathrm{min}$; Air atmosphere).

\subsection{Rehydration studies}

The anhydrous compound 2 was prepared from 1 as mentioned above. Equilibration of a powdered sam- ple of $\mathbf{2}$ over water vapour resulted in the formation of the starting material 1 in near quantitative yield in about a day. The IR spectra and DSC thermogram of the rehydrated compound is identical to that of 1 .

\section{$2.5 X$-ray crystallography}

Intensity data for 1 were collected on a Bruker Smart Apex CCD diffractometer using graphite-monochromated Mo-K $\mathrm{K}_{\alpha}$ radiation $(\lambda=0.71073 \AA)$. The data integration and reduction were processed with SAINT $^{15}$ software. An empirical absorption correction was applied to the collected reflections with SADABS. ${ }^{16}$ The structure was solved with direct methods using SHELXS-97 ${ }^{17}$ and refinement was done against $F^{2}$ using SHELXL-97. ${ }^{17}$ All nonhydrogen atoms were refined anisotropically. Aromatic hydrogens were introduced on calculated positions and included in the refinement riding on their respective parent atoms. The hydrogen atoms of the coordinated water molecules were located in the difference map but were not stable on subsequent refinements and hence were fixed at calculated 
Table 2. Selected bond distances $(\AA)$ for $\left[\left[\mathrm{Ba}\left(\mathrm{H}_{2} \mathrm{O}\right)_{3}\right]_{2}\left(\mu_{2}-2-n b a-O, O, O-\right.\right.$ $\left.\left.\mathrm{NO}_{2}\right)_{2}\left(\mu_{2}-2 \text {-nba-O,O, } \mathrm{O}^{\prime}\right)_{2}\right]_{n} \mathbf{1}$.

\begin{tabular}{llll}
\hline $\mathrm{Ba}(1)-\mathrm{O}(5)$ & $2 \cdot 703(2)$ & $\mathrm{Ba}(1)-\mathrm{O}(1)$ & $2 \cdot 816(2)$ \\
$\mathrm{Ba}(1)-\mathrm{O}(11)$ & $2 \cdot 744(2)$ & $\mathrm{Ba}(1)-\mathrm{O}(1)^{\mathrm{ii}}$ & $2 \cdot 833(2)$ \\
$\mathrm{Ba}(1)-\mathrm{O}(10)$ & $2 \cdot 767(3)$ & $\mathrm{Ba}(1)-\mathrm{O}(3)$ & $2 \cdot 900(2)$ \\
$\mathrm{Ba}(1)-\mathrm{O}(6)^{\mathrm{i}}$ & $2 \cdot 777(2)$ & $\mathrm{Ba}(1)-\mathrm{O}(5)^{\mathrm{i}}$ & $2 \cdot 906(2)$ \\
$\mathrm{Ba}(1)-\mathrm{O}(9)$ & $2 \cdot 807(4)$ & $\mathrm{Ba}(1)-\mathrm{Ba}(1)^{\mathrm{i}}$ & $4 \cdot 5406(15)$ \\
$\mathrm{Ba}(1)-\mathrm{Ba}(1)^{\mathrm{ii}}$ & $4 \cdot 5726(14)$ & & \\
\hline
\end{tabular}

Symmetry transformations are used to generate equivalent atoms; (i) $-x+1$, $-y+1,-z+1$; (ii) $-x+1,-y+2,-z+1$

positions by using DFIX command and later refined isotropically using a riding model. The technical details of data acquisition and some selected crystal refinement results for $\mathbf{1}$ are summarized in table 1.

\section{Results and discussion}

In an earlier study, the neutralization of a $0 \cdot 1 \mathrm{M}$ $\mathrm{Ba}(\mathrm{OH})_{2} \cdot 8 \mathrm{H}_{2} \mathrm{O}$ solution by a $0 \cdot 2 \mathrm{M} 2-\mathrm{nbaH}$ solution has been shown to result in the formation of the water soluble barium(II) o-nitrobenzoate trihydrate. ${ }^{18}$ In the present work, we have used either $\mathrm{BaCO}_{3}$ or $\mathrm{BaCl}_{2}$ as the $\mathrm{Ba}$ (II) source. The aqueous reaction of $\mathrm{BaCO}_{3}$ with 2-nbaH resulted in the formation of the nine coordinated compound $\left[\left[\mathrm{Ba}\left(\mathrm{H}_{2} \mathrm{O}\right)_{3}\right]_{2}\left(\mu_{2}-2\right.\right.$-nba$\left.\left.\mathrm{O}, \mathrm{O}, \mathrm{O}-\mathrm{NO}_{2}\right)_{2}\left(\mu_{2}-2-n b a-\mathrm{O}, \mathrm{O}, \mathrm{O}^{\prime}\right)_{2}\right]_{n}$ 1. Alternatively, 1 can be prepared by reacting an aqueous $\mathrm{BaCl}_{2}$ with in situ generated sodium 2-nba. The observed analytical and spectral characteristics of compound $\mathbf{1}$ are in good agreement with the previously reported trihydrate. ${ }^{18}$ Crystals of $\mathbf{1}$ were characterized by elemental analysis, infrared and optical spectra, DSC thermogram, and single crystal X-ray structure determination. As the solid state structure of compound 1 (vide infra) turned out to be a one-dimensional polymer, the reaction of the water soluble compound 1 was investigated with aqueous sulfate. The reaction of an aqueous solution of 1 with aqueous $\mathrm{Na}_{2} \mathrm{SO}_{4}$ resulted in the immediate precipitation of $\mathrm{BaSO}_{4}$ in quantitative yield. It cannot be unambiguously stated that the polymeric structure of 1 does not persist in solution, based only on its behaviour towards sulfate. Nevertheless this reaction constitutes a convenient method for the incorporation of 2-nba anions in the place of $\left(\mathrm{SO}_{4}\right)^{2-}$ in other metal sulfates. The use of the title compound as a convenient source for delivering 2-nba assumes importance in view of the reported behaviour of 2-nba compounds to exhibit polymorphism. ${ }^{19}$

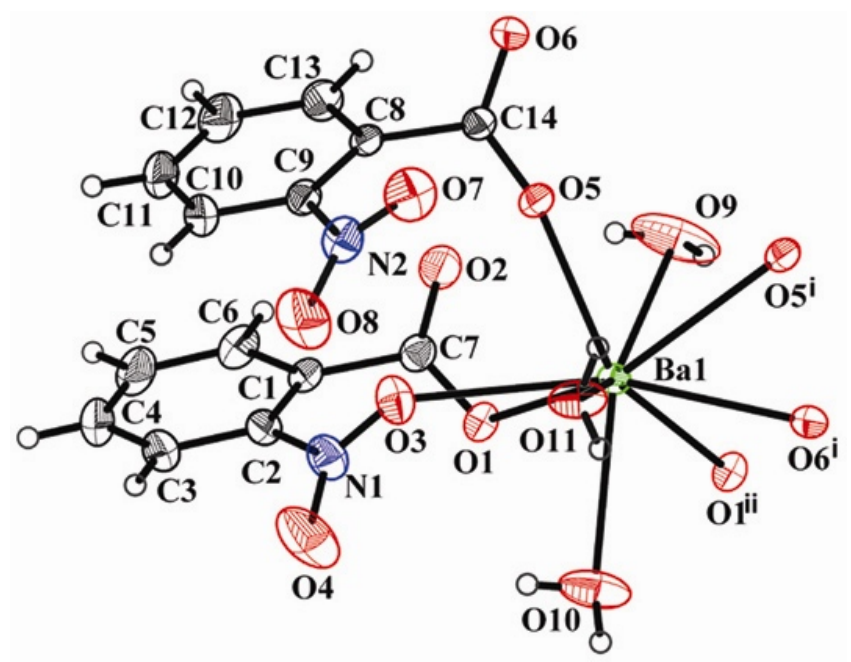

Figure 2. The coordination sphere of $\mathrm{Ba}(\mathrm{II})$ in $\left[\left[\mathrm{Ba}\left(\mathrm{H}_{2} \mathrm{O}\right)_{3}\right]_{2}\left(\mu_{2}-2 \text {-nba-O,O,O-NO }\right)_{2}\left(\mu_{2} \text {-2-nba-O,O, } \mathrm{O}^{\prime}\right)_{2}\right]_{n}$ 1 showing the atom-labelling scheme. Displacement ellipsoids are drawn at the $50 \%$ probability level except for the $\mathrm{H}$ atoms, which are shown as circles of arbitrary radius. Symmetry code: (i) $[-x+1,-y+1,-z+1]$; (ii) $[-x+1,-y+2,-z+1]$.

Heating of 1 on a steam bath results in the formation of the anhydrous barium(II) bis(2-nitrobenzoate) 2 while the pyrolysis of $\mathbf{1}$ or $\mathbf{2}$ in a Bunsen flame results in the formation of $\mathrm{BaCO}_{3} .1$ absorbs strongly in the UV region at $274 \mathrm{~nm}$, which can be assigned to the intramolecular charge transfer transition of the aromatic carboxylate. The IR spectra of 1 and $\mathbf{2}$ (see web version) exhibit several sharp bands in the midinfrared region, clearly indicating the presence of the organic moiety. The broad and strong signal in the region $3730-2922 \mathrm{~cm}^{-1}$ in 1 indicates the presence of water and can be assigned to the $\mathrm{O}-\mathrm{H}$ stretching vibration. The IR spectrum of $\mathbf{2}$ is devoid of bands above $3100 \mathrm{~cm}^{-1}$, which is indicative of the anhydrous nature of 2 . The spectrum below $3100 \mathrm{~cm}^{-1}$, is similar to that of $\mathbf{1}$. Although the IR spectra $\mathbf{1}$ and $\mathbf{2}$ exhibit the absorptions due to the vibrations of the 

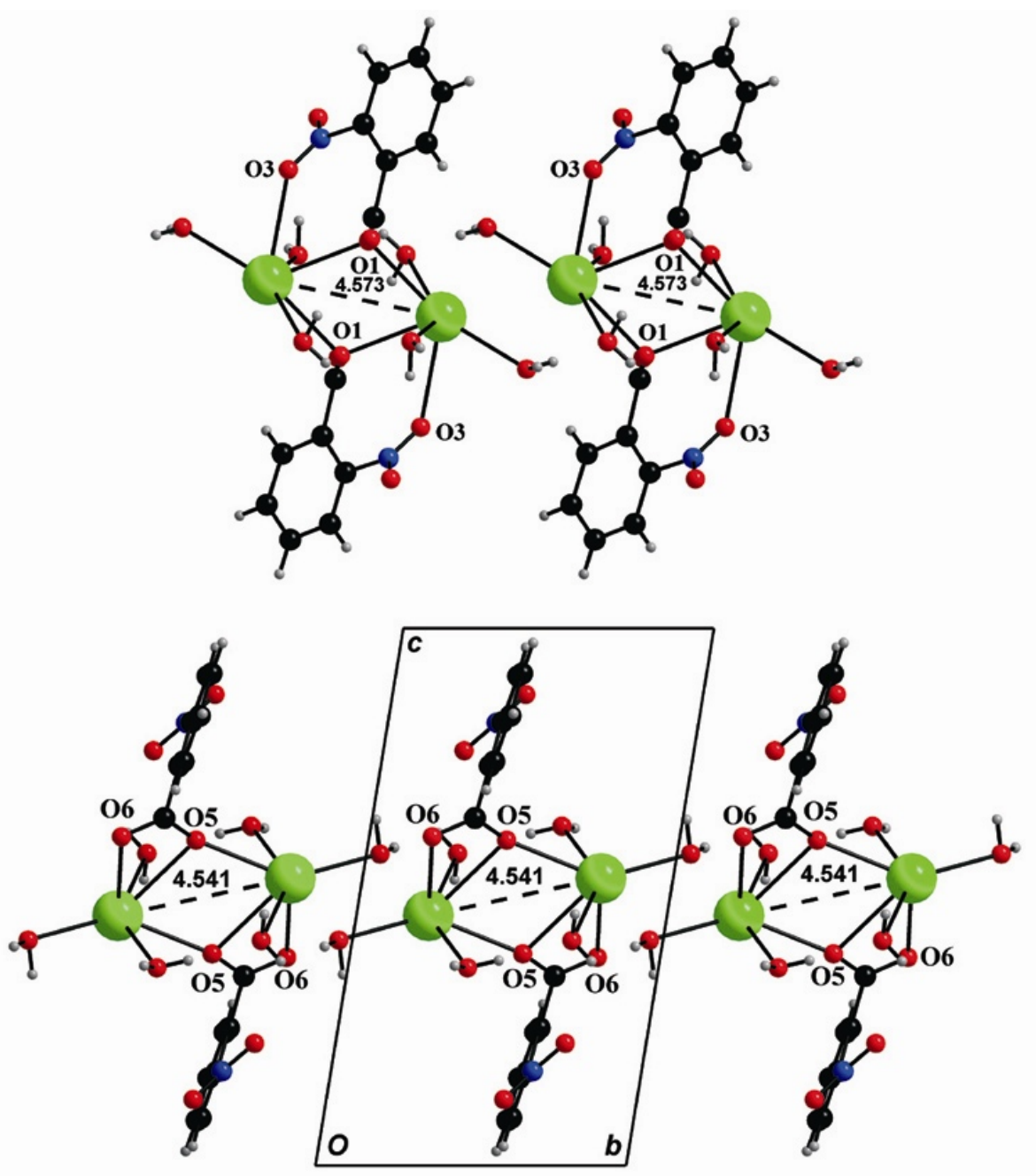

Figure 3. A view along $a$ showing the dimeric units of $\left[\mathrm{Ba}\left(\mathrm{H}_{2} \mathrm{O}\right)_{3}\left(\mu_{2}-2-n b a-\mathrm{O}, \mathrm{O}, \mathrm{O}-\right.\right.$ $\left.\mathrm{NO}_{2}\right)_{2}$ ] formed by the tridentate ligand $\left(\mu_{2}-2\right.$-nba-O,O,O-NO$\left.{ }_{2}\right)$. Each $\mathrm{Ba}(\mathrm{II})$ is linked to a nitro oxygen $\mathrm{O} 3$ and both the $\mathrm{Ba}(\mathrm{II})$ are bridged by the carboxylate oxygen $\mathrm{O} 1$ (top). A view along $a$ of the dimeric units $\left[\mathrm{Ba}\left(\mathrm{H}_{2} \mathrm{O}\right)_{3}\left(\mu_{2}-2 \text {-nba-O,O, } \mathrm{O}^{\prime}\right)_{2}\right]$ formed by the tridentate ligand $\left(\mu_{2}-2-n b a-O, O, \mathrm{O}^{\prime}\right)$. Each $\mathrm{Ba}(\mathrm{II})$ is linked to $\mathrm{O} 5$ and $\mathrm{O} 6$ and both the $\mathrm{Ba}(\mathrm{II})$ in the dimer are bridged by the carboxylate oxygen $\mathrm{O} 5$ (bottom).

carboxylate and nitro groups, no definite conclusions can be drawn on the nature of the binding of the 2-nba ligand based on infrared data alone.

The TG-DSC thermogram of 1 (figure 1) exhibits an endothermic event at around $88^{\circ} \mathrm{C}$ accompanied by a mass loss of $10.5 \%$ assignable for the removal of three molecules of water. The dehydration process is followed by an endothermic signal at around $230^{\circ} \mathrm{C}$, which can be assigned to a phase change. Above this temperature, $\mathbf{1}$ undergoes a complex decomposition process as evidenced by the strong exothermic events at 338 and $444^{\circ} \mathrm{C}$. In the absence of mass spectral data of the emitted fragments no defi- nite conclusions can be drawn on the exact nature of the decomposition processes. The observed residue is in good agreement for the formation of $\mathrm{BaCO}_{3}$. The results of the isothermal weight loss studies at $100^{\circ} \mathrm{C}$ (steam bath) and at $800^{\circ} \mathrm{C}$ add credence to the TG-DSC data. As expected, the TG-DSC thermogram of the anhydrous compound 2 (see web version) is devoid of the first endothermic signal observed for the dehydration of 1 and the thermal decomposition pattern of $\mathbf{2}$ is similar to that of $\mathbf{1}$ above this temperature, resulting in the formation of $\mathrm{BaCO}_{3}$ residue. Equilibriation of the anhydrous compound $\mathbf{2}$ in an atmosphere of water vapour results 


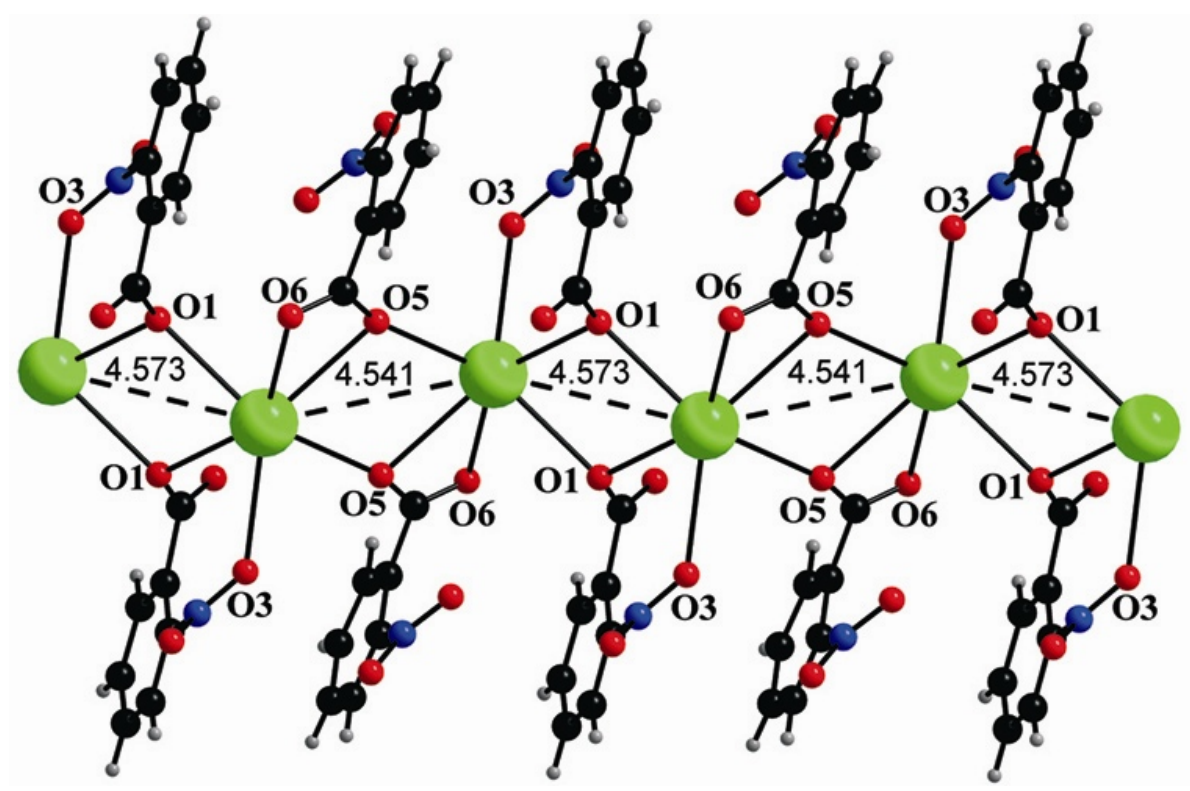

Figure 4. A view along $a$ showing the 1-D polymeric chain of 1. Alternating pairs of $\mathrm{Ba}(\mathrm{II})$ ions are linked by a pair of tridentate $\left(\mu_{2}-2-\mathrm{nba}-\mathrm{O}, \mathrm{O}, \mathrm{O}-\mathrm{NO}_{2}\right)$ and $\left(\mu_{2}-2-\mathrm{nba}-\mathrm{O}, \mathrm{O}, \mathrm{O}^{\prime}\right)$ ligands resulting in alternating $\mathrm{Ba} \cdots \mathrm{Ba}$ distances of $4 \cdot 5406(15)$ and $4 \cdot 5726(14) \AA$. For clarity, the coordinated water molecules on $\mathrm{Ba}(\mathrm{II})$ are not shown.

in the regeneration of compound $\mathbf{1}$ as confirmed by a comparison of the IR spectrum of the rehydrated product with that of 1 .

The coordination polymer $\left[\left[\mathrm{Ba}\left(\mathrm{H}_{2} \mathrm{O}\right)_{3}\right]_{2}\left(\mu_{2}-2\right.\right.$-nba$\left.\left.\mathrm{O}, \mathrm{O}, \mathrm{O}-\mathrm{NO}_{2}\right)_{2}\left(\mu_{2}-2 \text {-nba-O }, \mathrm{O}, \mathrm{O}^{\prime}\right)_{2}\right]_{n} \mathbf{1}$ crystallizes in the centrosymmetric triclinic space group $\mathrm{P}_{\overline{1}}$ and all atoms are located in general positions. The observed $\mathrm{Ba}-\mathrm{O}$ bond distances vary between 2.703(2) and 2.906(2) A (table 2). These values are comparable with those reported for other $\mathrm{Ba}$ (II)-carboxylates. ${ }^{12,20}$ In the crystal structure, the $\mathrm{Ba}(\mathrm{II})$ is nine coordinated and is bonded to three $\mathrm{O}$ atoms from the three aqua ligands and six oxygen atoms from four symmetry related 2-nba anions (figure 2). The central metal is linked to the $\mathrm{O}$ atoms $(\mathrm{O} 9-\mathrm{O} 11)$ of three water molecules and the $\mathrm{Ba}-\mathrm{O}\left(\mathrm{H}_{2} \mathrm{O}\right)$ distances range from $2 \cdot 744(2)$ to $2 \cdot 807(4) \AA$.

The polymeric structure is based on a dimer and each formula unit of 1 contains three coordinated water ligands and two unique 2-nitrobenzoate ligands both of which function as tridentate ligands in different fashion. The first unique 2-nba ligand $(\mathrm{O} 1, \mathrm{O} 2, \mathrm{O} 3)$ functions as a monoatomic bridging ligand, linking two symmetry related $\mathrm{Ba}(\mathrm{II})$ ions via $\mathrm{O} 1$ with $\mathrm{Bal}-\mathrm{O} 1$ bond distances of 2.816(2) and 2.833 (2) $\AA$ respectively. It is interesting to note that the $\mathrm{O} 3$ oxygen of the nitro functionality makes a Ba1-03 bond at 2.900(2) $\AA$. This unique tridentate 2-nba ligand is designated as $\left(\mu_{2}-2-n b a-0,0,0-\mathrm{NO}_{2}\right)$. It is to be noted that the proximity of the nitro group to the carboxylate has resulted in this bond. A similar behaviour was earlier reported for the 2Dcoordination polymer of $\mathrm{Ba}(\mathrm{II})$ derived from 2aminobenzoic acid with a Ba-N bond at 3.047(4) $\AA^{20}$ To the best of our knowledge compound 1 constitutes the first example of a structurally characterized 2nitrobenzoate showing a coordinated nitro group. The second independent 2-nba ligand $(\mathrm{O} 5, \mathrm{O} 6)$ also functions as a tridentate ligand with each $\mathrm{Ba}(\mathrm{II})$ linked to $\mathrm{O} 5$ and $\mathrm{O} 6$ in a bidentate manner (Bal-O5 2.703(2); Bal-O6 2.777(2) $\AA$ ) and the O5 further linked to a symmetry related $\mathrm{Ba}(\mathrm{II})$ ion at 2.906(2) $\AA$ resulting in a monoatomic bridging mode. However, the nitro oxygen atoms are not at bonding distance to $\mathrm{Ba}(\mathrm{II})$ for this ligand. This second tridentate 2nba ligand is designated as $\left(\mu_{2}-2-n b a-O, O, O^{\prime}\right)$. The structure of 1 can be explained as being composed of a pair of $\left\{\mathrm{Ba}\left(\mathrm{H}_{2} \mathrm{O}\right)_{3}\right\}$ units linked via two $\mu_{2}-$ carboxylate bridges by a pair of $\left(\mu_{2}-2-n b a-0,0,0-\right.$ $\left.\mathrm{NO}_{2}\right)$ ligands leading to $\mathrm{a}\left(\mathrm{Ba}_{2} \mathrm{O}_{2}\right)$ four-membered ring

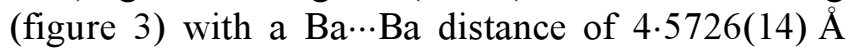
resulting in the formation of dimeric units of composition $\left.\quad\left[\mathrm{Ba}\left(\mathrm{H}_{2} \mathrm{O}\right)_{3}\left(\mu_{2} \text {-2-nba-O,O,O-NO }\right)_{2}\right)_{2}\right]_{2}$ along $b$ axis. The linking of a pair of $\left\{\mathrm{Ba}\left(\mathrm{H}_{2} \mathrm{O}\right)_{3}\right\}$ units by a pair of tridentate $\left(\mu_{2}-2\right.$-nba- $\left.O, O, O^{\prime}\right)$ ligands results in the formation of dimeric units of 
Table 3. Hydrogen-bonding geometry $\left(\AA,^{\circ}\right)$ for $\left[\left[\mathrm{Ba}\left(\mathrm{H}_{2} \mathrm{O}\right)_{3}\right]_{2}\left(\mu_{2}-2-n b a-O, O, O-\right.\right.$ $\left.\left.\mathrm{NO}_{2}\right)_{2}\left(\mu_{2}-2 \text {-nba-O,O, } \mathrm{O}^{\prime}\right)_{2}\right]_{n} \mathbf{1}$.

\begin{tabular}{|c|c|c|c|c|}
\hline $\mathrm{D}-\mathrm{H} \cdots \mathrm{A}$ & $d(\mathrm{D}-\mathrm{H})$ & $d(\mathrm{H} \cdots \mathrm{A})$ & $\mathrm{D}(\mathrm{D} \cdots \mathrm{A})$ & $<$ DHA \\
\hline O11-H11A $\cdots \mathrm{O}^{\mathrm{i}}$ & 0.836 & 1.949 & $2 \cdot 780$ & 173 \\
\hline O9-H9A $\cdots$ O $10^{\text {ii }}$ & 0.797 & $2 \cdot 275$ & 2.775 & 121 \\
\hline $\mathrm{O} 10-\mathrm{H} 10 \mathrm{~A} \cdots \mathrm{O} 6^{\mathrm{iii}}$ & $0 \cdot 857$ & 1.899 & $2 \cdot 752$ & 174 \\
\hline $\mathrm{O} 11-\mathrm{H} 11 \mathrm{~B} \cdots \mathrm{O} 2^{\text {iv }}$ & $0 \cdot 847$ & $1 \cdot 870$ & $2 \cdot 714$ & 175 \\
\hline O9-H9B..O2 & $0 \cdot 817$ & $2 \cdot 429$ & $3 \cdot 224$ & 165 \\
\hline $\mathrm{C} 12-\mathrm{H} 12 \cdots \mathrm{O} 8^{\mathrm{v}}$ & $0 \cdot 930$ & $2 \cdot 689(3)$ & $3 \cdot 612$ & 172 \\
\hline
\end{tabular}

Symmetry Code: (i) $-x+1,-y+1,-z+1$; (ii) $-x+1,-y+2,-z+1$; (iii) $x-1$, $y+1, z$; (iv) $x-1, y, z$; (v) $x+1, y, z$

composition $\left[\mathrm{Ba}\left(\mathrm{H}_{2} \mathrm{O}\right)_{3}\left(\mu_{2}-2 \text {-nba- } \mathrm{O}, \mathrm{O}, \mathrm{O}^{\prime}\right)_{2}\right]_{2}$ along $b$ axis (figure 3). It is interesting to note that this binding mode of 2-nba results in a $\mathrm{Ba} \cdots \mathrm{Ba}$ separation of 4.5406(15) $\AA$, which is slightly shorter than the Ba $\cdots$ Ba separation observed earlier for the tridentate 2-nba ligand binding through the nitro oxygen. The extended structure is arrived at by the linking of two $\left[\mathrm{Ba}\left(\mathrm{H}_{2} \mathrm{O}\right)_{3}\left(\mu_{2}-2-\text { nba-O, O,O-NO } \mathrm{NO}_{2}\right)_{2}\right]$ units by a pair of $\left(\mu_{2}-2\right.$-nba-O,O, $\left.\mathrm{O}^{\prime}\right)$ ligands. Thus the two different tridentate 2-nba ligands link the $\left\{\mathrm{Ba}\left(\mathrm{H}_{2} \mathrm{O}\right)_{3}\right\}$ units into a one-dimensional polymeric chain extending along $b$. In the infinite chain, each nine coordinated $\mathrm{Ba}(\mathrm{II})$ is bonded to three water molecules and further linked to six oxygen atoms of four different 2nba anions with alternating pairs of $\mathrm{Ba}$ (II) ions in the chain bridged by a pair of $\left(\mu_{2}-2-n b a-O, O^{\prime}, O-\right.$ $\left.\mathrm{NO}_{2}\right)$ and $\left(\mu_{2}-2-\mathrm{nba}-\mathrm{O}, \mathrm{O}, \mathrm{O}^{\prime}\right)$ ligands resulting in alternating $\mathrm{Ba} \cdots \mathrm{Ba}$ distances of $4.5406(15)$ and 4.5726(14) $\AA$ across the chain (figure 4).

An analysis of the crystal structure of 1 reveals that each nine coordinated $\mathrm{Ba}$ (II) complex in the polymeric chain is H-bonded to neighbouring complexes in the polymeric chain with the aid of two varieties of H-bonding interactions. All the hydrogen atoms attached to the coordinated waters excepting H10B and one hydrogen atom on a benzene ring function as $\mathrm{H}$-donors. Two oxygen atoms from the coordinated water molecules $\mathrm{O} 9$ and $\mathrm{O} 10$, the free carboxylate oxygen $\mathrm{O} 2$ and a coordinated oxygen $\mathrm{O} 6$ and the nitro oxygen $\mathrm{O} 8$ function as $\mathrm{H}$-acceptors. Thus each $\mathrm{Ba}$ (II) complex in $\mathbf{1}$ is linked to five other complexes with the aid of five $\mathrm{O}-\mathrm{H} \cdots \mathrm{O}$ bonds and a $\mathrm{C}-\mathrm{H} \cdots \mathrm{O}$ interaction (table 3 ). The $\mathrm{C}-\mathrm{H} \cdots \mathrm{O}$ interaction between the nitro oxygen $\mathrm{O} 8$ and an aromatic $\mathrm{H}$ serves to link parallel chains resulting in a twodimensional H-bonded network (see web version).

The short ring interactions and distances between the ring centroids $(\mathrm{Cg}-\mathrm{Cg})$ in $\mathbf{1}$ were analysed by us- ing the program PLATON. ${ }^{21}$ The $\mathrm{Cg}-\mathrm{Cg}$ distance between the two 2-nba ligands is $4.089 \AA$ and the perpendicular distance from the centre of the first ring to the second (interplanar distance) is $3.644 \AA$ accompanied by a dihedral angle of $5.58^{\circ}$. These values indicate that the rings do not overlap and the magnitude of the values is suggestive of no stacking interactions.

The availability of structural information of many $\mathrm{Ba}$ (II) coordination polymers of varying dimensionalities derived from several carboxylic acids permits a comparative study of $\mathrm{Ba}$ (II) coordination polymers. ${ }^{22-33}$ In these compounds the $\mathrm{Ba} \cdots \mathrm{Ba}$ distance across the polymeric chain varies from 4.069(2) in the three dimensional (3-D) coordination polymer derived from 2,2'-dithiobis(benzoic acid) to $7.467 \AA$ in the 1-D $\mathrm{Ba}$ (II) polymer derived from the $\mathrm{N}$-substituted amino acid containing the N-(6-amino-3,4-dihydro3-methyl-5-nitroso-4-oxopyrimidin-2-yl) group (table 4). In all these compounds, the carboxylate anions function as bridging ligands. The coordination number of $\mathrm{Ba}$ (II) varies from 8 to 10 with nine coordination observed in several compounds. In four of the polymers the $\mathrm{Ba} \cdots \mathrm{Ba}$ separations are shorter than the sum of the van der Waals radii $(4 \cdot 28 \AA)$ indicating weak metal-metal interactions, while in other compounds the observed metal-metal contacts are longer. Interestingly, the observed $\mathrm{Ba} \cdots \mathrm{Ba}$ distances of 4.5406(15) and 4.5726(14) $\AA$ in 1 are much shorter than the $\mathrm{Ba} \cdots \mathrm{Ba}$ separation of $6.750(1) \AA$ in the related 1-D polymer $\left[\mathrm{Ba}\left(\mathrm{H}_{2} \mathrm{O}\right)_{5}(4-\mathrm{nba})_{2}\right]_{n}$ derived from 4-nitrobenzoic acid where the nitro group is disposed trans to the carboxylate. It is to be noted that the polymeric complex $\left[\mathrm{Ba}\left(\mathrm{H}_{2} \mathrm{O}\right)_{5}(4-\mathrm{nba})_{2}\right]_{n}$ contains two unique 4-nba ligands one of which functions as a bidentate ligand with the other functioning as a bridging bidentate ligand. ${ }^{12}$ In the $\mathrm{Ba}$ (II) polymer of 4-nba the oxygen atoms of the nitro 
Table 4. Ba $\cdots$ Ba distances across the chain in some $\mathrm{Ba}(\mathrm{II})$ coordination polymers containing bridging carboxylates.

\begin{tabular}{|c|c|c|c|c|}
\hline Compound & C.N. & $\begin{array}{c}\mathrm{Ba} \cdots \mathrm{Ba}^{\prime} \\
\text { distance }(\AA)\end{array}$ & $\begin{array}{l}\text { Dimensionality } \\
(D) \text { of polymer }\end{array}$ & Reference \\
\hline$\left[\left\{\mathrm{Ba}_{2}(\mathrm{DTBB})_{2}\left(\mathrm{H}_{2} \mathrm{O}\right)_{2}\right\} 0 \cdot 5 \mathrm{H}_{2} \mathrm{O}\right]_{n}^{\#}$ & $9,8,8$ & $4 \cdot 069(2)$ & $3-\mathrm{D}$ & 22 \\
\hline$\left[\mathrm{Ba}\left(\mathrm{C}_{6} \mathrm{H}_{4}(\mathrm{COO})_{2}\right)\right]_{n}$ & 8 & $4 \cdot 123$ & $3-\mathrm{D}$ & 23 \\
\hline$\left[\mathrm{Ba}(\mathrm{Hbpdc})_{2}\left(\mathrm{H}_{2} \mathrm{O}\right)_{2}\right]_{n}$ & 9 & $4 \cdot 1386(17)$ & $1-\mathrm{D}$ & 24 \\
\hline$\left[\mathrm{Ba}_{9}\left(\mathrm{CH}_{3} \mathrm{COO}\right)_{14}\left(\mathrm{ClO}_{4}\right)_{4}\right]_{n}^{\#}$ & $8,9,9$ & $4 \cdot 27$ & $3 \mathrm{D}$ & 25 \\
\hline$\left[\mathrm{Ba}(2-\mathrm{aba})_{2}\left(\mathrm{H}_{2} \mathrm{O}\right)_{2}\right]_{n}$ & 9 & $4 \cdot 32$ & $2-\mathrm{D}$ & 20 \\
\hline$\left[\mathrm{Ba}\left(\mathrm{C}_{7} \mathrm{H}_{5} \mathrm{O}_{2} \mathrm{~S}\right)_{2}\left(\mathrm{H}_{2} \mathrm{O}\right)_{4}\right]_{n}$ & 9 & $4 \cdot 335$ & $1-\mathrm{D}$ & 26 \\
\hline$\left[\mathrm{Ba}\left(\mathrm{C}_{8} \mathrm{H}_{5} \mathrm{O}_{3}\right)_{2}\left(\mathrm{H}_{2} \mathrm{O}\right)_{2}\right]_{n}$ & 8 & $4 \cdot 4336(3)$ & $1-\mathrm{D}$ & 27 \\
\hline$\left[\left[\mathrm{Ba}(\mathrm{PY}-\mathrm{met})_{2}\left(\mathrm{H}_{2} \mathrm{O}\right)_{4}\right] \cdot 3 \mathrm{H}_{2} \mathrm{O}\right]_{n}$ & 10 & $4 \cdot 4451(2)$ & $3-\mathrm{D}$ & 28 \\
\hline$\left[\left[\mathrm{Ba}\left(\mathrm{H}_{2} \mathrm{O}\right)_{3}(2-\mathrm{nba})_{2}\right]_{2}\right]_{n} \mathbf{1}$ & 9 & $\begin{array}{l}4 \cdot 5406(15) \\
4 \cdot 5726(14)\end{array}$ & $1-\mathrm{D}$ & This work \\
\hline$\left[\mathrm{Ba}\left(\mathrm{C}_{5} \mathrm{H}_{4} \mathrm{O}_{4}\right)_{2}\left(\mathrm{H}_{2} \mathrm{O}\right)_{4}\right]_{n}$ & 9 & $4 \cdot 595(4)$ & $2-\mathrm{D}$ & 29 \\
\hline$\left[\mathrm{Ba}(1,3-\mathrm{BDOA})\left(\mathrm{H}_{2} \mathrm{O}\right)_{2}\right]_{n}$ & 10 & $4 \cdot 755(3)$ & $3-\mathrm{D}$ & 30 \\
\hline$\left[\mathrm{Ba}\left(\mathrm{C}_{10} \mathrm{H}_{12} \mathrm{~N}_{5} \mathrm{O}_{6}\right)_{2}\left(\mathrm{H}_{2} \mathrm{O}\right)_{6}\right]_{n}$ & 9 & $6 \cdot 575(0)$ & $1-\mathrm{D}$ & 31 \\
\hline$\left[\mathrm{Ba}\left(\mathrm{H}_{2} \mathrm{PMA}\right)\left(\mathrm{H}_{2} \mathrm{O}\right)_{5}\right]_{n}$ & 9 & $6 \cdot 65$ & $2-\mathrm{D}$ & 32 \\
\hline$\left[\mathrm{Ba}\left(\mathrm{H}_{2} \mathrm{O}\right)_{5}(4-\mathrm{nba})_{2}\right]_{n}$ & 9 & $6 \cdot 750(1)$ & $1-\mathrm{D}$ & 12 \\
\hline$\left[\left[\mathrm{Ba}\left(\mathrm{H}_{2} \mathrm{IDC}\right)_{2}\left(\mathrm{H}_{2} \mathrm{O}\right)_{4}\right] \cdot 2 \mathrm{H}_{2} \mathrm{O}\right]_{n}$ & 10 & $6 \cdot 765(3)$ & $2-\mathrm{D}$ & 33 \\
\hline$\left[\left[\mathrm{Ba}(\mathrm{PY} \text {-glycinato })_{2}\left(\mathrm{H}_{2} \mathrm{O}\right)_{5}\right] \cdot \mathrm{H}_{2} \mathrm{O}\right]_{n}$ & 9 & $6 \cdot 916(1)$ & $1-\mathrm{D}$ & 28 \\
\hline$\left[\left[\mathrm{Ba}(\mathrm{PY} \text {-serinato })_{2}\left(\mathrm{H}_{2} \mathrm{O}\right)_{4}\right] \cdot 3 \mathrm{H}_{2} \mathrm{O}\right]_{n}$ & 10 & $7 \cdot 139(0)$ & $1-\mathrm{D}$ & 28 \\
\hline$\left[\left[\mathrm{Ba}(\mathrm{PY} \text {-glycilglycinato })_{2}\left(\mathrm{H}_{2} \mathrm{O}\right)_{2}\right]_{n}\right.$ & 8 & $7 \cdot 467$ & $2-\mathrm{D}$ & 28 \\
\hline
\end{tabular}

Abbreviations used: $\mathrm{CN}=$ coordination number; " three unique $\mathrm{Ba}(\mathrm{II})$ ions; $\mathrm{DTBB}=2,2^{\prime}-$ dithiobis(benzoate); $\left.\left(\mathrm{C}_{6} \mathrm{H}_{4}(\mathrm{COO})_{2}\right)\right]=$ terephthalate; Hbpdc $=2^{\prime}$-carboxybiphenyl-2-carboxylate; 2-aba = 2-aminobenzoate; $\quad\left(\mathrm{C}_{7} \mathrm{H}_{5} \mathrm{O}_{2} \mathrm{~S}\right)=$ thiosalicylate; $\quad\left(\mathrm{C}_{8} \mathrm{H}_{5} \mathrm{O}_{3}\right)=2$-formylbenzoate; $\mathrm{PY}=\mathrm{N}$-(6-amino-3,4-dihydro-3-methyl-5-nitroso-4-oxopyrimidin-2-yl); met = monoanion of methionine; $\mathrm{C}_{5} \mathrm{H}_{4} \mathrm{O}_{4}=$ mesaconate anion; $\quad(1,3-\mathrm{BDOA})=m$-phenylenedioxyacetate; $\left(\mathrm{C}_{10} \mathrm{H}_{12} \mathrm{~N}_{5} \mathrm{O}_{6}\right)$ = N-4-amino-1,6-dihydro-1-methyl-5-nitroso-6-oxopyrimidin-2-yl)-(S)-glutamato; $\left(\mathrm{H}_{4} \mathrm{PMA}\right)=$ pyromellitic acid; 4-nba $=4$-nitrobenzoate; $\mathrm{H}_{2} \mathrm{IDC}=1 \mathrm{H}$-imidazole-4,5-dicarboxylato monoanion; *For 2-D and 3-D polymers only the shortest $\mathrm{Ba} \cdots \mathrm{Ba}$ contact is given.

group are not involved in coordination unlike in compound 1 . It is interesting to note that both the oxygen atoms of the nitro functionalities in both the unique 4-nba ligands in $\left[\mathrm{Ba}\left(\mathrm{H}_{2} \mathrm{O}\right)_{5}(4-n b a)_{2}\right]_{n}$ are involved in $\mathrm{C}-\mathrm{H} \cdots \mathrm{O}$ interactions unlike in compound 1 where one oxygen atom $(\mathrm{O} 8)$ of the tridentate $\left(\mu_{2}-\right.$ 2-nba- $\mathrm{O}, \mathrm{O}, \mathrm{O}^{\prime}$ ) ligand is involved in $\mathrm{C}-\mathrm{H} \cdots \mathrm{O}$ bonding. In the $\mathrm{Ba}$ (II) coordination polymer derived from 2-aminobenzoic acid the $\mathrm{Ba}(\mathrm{II})$ exhibits a $\mathrm{Ba}-\mathrm{N}$ bond but the coordination polymer is threedimensional. Hence it appears that the $\mathrm{Ba} \cdots \mathrm{Ba}$ distances in Ba-carboxylate coordination polymers are probably determined by a combination of several factors, which include the electronic and steric requirements of the central metal, the denticity, flexibility, bridging behaviour and H-bonding characteristics of the carboxylate ligand.

\section{Conclusions}

In summary, we have described the synthesis, structural characterization and properties of a one-dimen- sional $\mathrm{Ba}(\mathrm{II})$ coordination polymer 1 , containing 2 -nba as a bridging ligand. Compound 1 constitutes an example of a structurally characterized 2-nitrobenzoate showing nitro ligation. The observed $\mathrm{Ba} \cdots \mathrm{Ba}$ distances of 4.5406(15) and 4.5726(14) $\AA$ across the chain in the 1-D polymer $\mathbf{1}$ are much shorter than the $\mathrm{Ba} \cdots \mathrm{Ba}$ separation of $6 \cdot 750(1) \AA$ between adjacent metal atoms in the 1-D polymeric $\mathrm{Ba}$ (II) compound of 4-nitrobenzoate. The reaction of the title compound with aqueous sulphate constitutes an useful method for the incorporation of 2-nba in lieu of sulphate. Current efforts in our laboratory are directed to exploit this reaction for the synthesis of new 2-nba compounds.

\section{Supplementary material}

Illustrations describing the infrared spectra of compounds 1 and 2, the TG-DSC thermogram of 2 and the crystallographic packing diagram of compound $\mathbf{1}$ are available on the web version of this paper. Crys- 
tallographic data (excluding structure factors) for the structure reported in this paper have been deposited with the Cambridge Crystallographic Data Centre as supplementary publication no. CCDC 666968. Copies of the data can be obtained, free of charge, on application to CCDC, 12 Union Road, Cambridge CB2 1 EZ, UK. (fax: +44-(0)1223-336033 or email: deposit@ccdc.cam.ac.uk).

\section{Acknowledgements}

BRS thanks Dr Samar K Das School of Chemistry, University of Hyderabad, for the X-ray intensity data of 1 . This work was supported by the Department of Science and Technology, New Delhi under grant no. SR/S 1/IC-41/2003.

\section{References}

1. Mehrotra R C and Bohra M 1983 Metal carboxylates (Academic Press: London); Mehrotra R C and Singh A 1997 Prog. Inorg. Chem. 46239

2. Cotton F A, Wilkinson G, Murillo C A and Bochmann M 1999 Advanced Inorganic Chemistry (Chichester: John Wiley \& Sons, Inc.), 6th edn, p. 487

3. Rao C N R, Natarajan S and Vaidhyanathan R 2004 Angew. Chem. Int. Ed. 431466

4. Rowsell J L C and Yaghi O M $2006 \mathrm{~J}$. Am. Chem. Soc. 1261304

5. Srinivasan B R, Sawant S C and Dhuri S N 2002 Indian J. Chem. A41 290

6. Srinivasan B R and Sawant S C 2003 Thermochim. Acta $\mathbf{4 0 2} 45$

7. Srinivasan B R, Sawant S C and Das S K 2004 Indian J. Chem. A43 1066

8. Srinivasan B R, Sawant J V and Raghavaiah P 2007 J. Chem. Sci. 11911

9. Srinivasan B R, Sawant J V, Näther C and Bensch W 2007 J. Chem. Sci. 119243

10. Srinivasan B R, Sawant J V and Raghavaiah P 2006 Indian J. Chem. A45 2392

11. Srinivasan B R, Raghavaiah P and Sawant J V 2007 Acta Crystallogr. $\mathbf{E 6 3} \mathrm{m} 2251$
12. Srinivasan B R, Sawant J V, Sawant S C and Raghavaiah P 2007 J. Chem. Sci. 119593

13. Swisłocka R, Samsonowicz M, Regulska E and Lewandowski W 2007 J. Mol. Struct. 834-836 389

14. Swisłocka R, Oleksinski E, Regulska E, Kalinowska M and Lewandowski W 2007 J. Mol. Struct. 834-836 380

15. Bruker SMART V5.630 and SAINT-PLUS V6.45, Bruker-Nonius Analytical X-ray Systems Inc.: Madison, Wisconsin, USA, 2003

16. SADABS 1997 Empirical absorption correction program, Bruker AXS Inc., Madison, Wisconsin, USA

17. Sheldrick G M 2008 Acta Crystallogr. A64 112

18. Charbonnier F, Balek V and Bussiere P $1975 \mathrm{~J}$. Thermal Anal. 7373

19. Karmakar A, Sarma R J and Baruah J B 2006 Eur. J. Inorg. Chem. 643

20. Murugavel R, Karambelkar V V, Anantharaman G and Walawalkar M G 2000 Inorg. Chem. 391381

21. Spek A L 2003 J. Appl. Cryst. 367

22. Murugavel R, Baheti K and Anantharaman G 2001 Inorg. Chem. 406870

23. Lee B H, Kim C H and Lee S G 2003 Acta Crystallogr. C59 m196

24. Briceno A, Delgado J M and Delgado G D 2002 Acta Crystallogr. $\mathbf{E 5 8} \mathrm{m} 602$

25. Dong $\mathrm{G}$, Bing-guang $\mathrm{Z}$, Ke-liang $\mathrm{P}$, Chun-ying D and Qing-jin M $2002 \mathrm{~J}$. Chem. Soc. Dalton Trans. 3783

26. Lo S M F, Chui S S Y and Williams I D 1998 Acta Crystallogr. C54 1846

27. Odabasoglu M and Büyükgüngör O 2006 Acta Crystallogr. E62 m402

28. Salido M L G, Mascaros P A, Garzon R L, Valero M D G, Low J N, Gallagher J F and Glidewell C 2004 Acta Crystallogr. B60 46

29. Djehni S, Balegroune F, Guehria-Laidoudi A, Dahaoui S and Lecomte C 2007 Acta Crystallogr. C63 m91

30. Gao S, Liu J W, Huo L H and Zhao H 2005 Acta Crystallogr. C61 m348

31. Garzon R L, Leon M D L, Low J N and Glidewell C 2005 Acta Crystallogr. C61 m224

32. Dale S H, Elsegood M R J and Kainth S 2003 Acta Crystallogr. C59 m505

33. Zhang X, Gao S, Huo L H and Zhao H 2005 Acta Crystallogr. E61 m2488 